\title{
UNDERGRADUATE DISPOSITIONS AND DISCIPLINE: ADDRESSING THE STRENGTH OF DISPOSITIONS POLICY IN INDIVIDUAL UNIVERSITY OF MAINE SYSTEM UNDERGRADUATE EDUCATION PROGRAMS
}

\begin{abstract}
Ross Daniel, Undergraduate Dispositions and Discipline: Addressing the Strength of Dispositions Policy in Individual University of Maine System Undergraduate Education Programs [Kształcenie dyspozycji przyszłych nauczycieli $\mathrm{w}$ programach edukacyjnych publicznych uniwersytetów w Maine]. Studia Edukacyjne nr 32, 2014, Poznań 2014, pp. 375-386. Adam Mickiewicz University Press. ISBN 978-83-232-2837-0. ISSN 1233-6688

Undergraduate student dispositions in the field of education are of prime concern to faculty and other professionals in the field. Just as medical professionals are expected to display appropriate "bedside manner", undergraduate teacher candidates are expected to develop dispositions and professional understandings that are observed in the field. Skills such as interpersonal communication with parents, children, site faculty and administration, along with timely written communication, attire, mannerism, planning, problem-solving, etc. are just a few examples of the skill sets that university education programs expect students to develop before graduation. A common problem for university education programs is that teaching dispositions to teacher candidates requires appropriate context. It is difficult to teach a student how to " scommunicate with parents" without having access to such groups.

In this writing, I plan to first explore the basis around which dispositions and discipline policies are crafted. Following that, using a framework suggested by Kaplin and Lee (Law of Higher Education, 2007), I will review dispositions policy contained in student teacher handbooks developed by the University of Maine System in terms of the strength of the language included.
\end{abstract}

Key words: University of Maine System, university education programs, teacher candidates

\section{Legal Basis and Cases}

Public institutions (the focus of this writing) may create rules for student conduct, and develop systems to determine whether a student has violated one or more rules and, if so, what punishment should be meted out. ${ }^{1}$ How-

${ }^{1}$ W. Kaplin, B. Lee, The Law of Higher Education, San Francisco 2007. 
ever, public institutions may not create policy that violates the protections afforded to individuals by the U.S. Constitution.

Dixon v. Alabama State Board of Education ${ }^{2}$ represents a shift from the older observance of in loco parentis (where institutions were recognized by courts as having the same authority over students that parents had over minor children) to recognizing students as adults with rights as such. In the Dixon case, a number of black students had been expelled from Alabama State College during civil rights protests on campus. Suit was brought on behalf of the plaintiff students against the Alabama State Board of Education as the students alleged the college had not provided them notice or an opportunity for hearing before expulsion, and the Fifth Circuit Court affirmed their case. As a result of Dixon, student relationships with institutions began to be looked upon by courts through a contractual perspective: students were contracting with institutions for services provided (instruction, and also sometimes room and board) in return for compensation (tuition and related fees).

Kaplin ${ }^{3}$ states that:

(...) courts are increasingly inclined to view the student handbook or college catalog as a contract. When problems arise in these areas, the written contract, including institutional regulations incorporated by reference in the contract, is usually the first source of legal guidance.

Institutions (to be understood as public universities for the purpose of this writing, unless specified otherwise) engage in self-regulation, and publish their policies as a preventative measure against liability. Colleges typically publish policy through student and/or departmental handbooks, which courts recognize as a form of contractual obligation. Additional sets of policies may be provided for students enrolled in specific coursework or internships. For example, University of Maine education students enrolled in student teaching (a culminating practice-teaching experience) will receive a student teaching handbook, which describes the parameters of the internship along with expectations for performance.

In addition to common expectations of academic performance and overall standing, many institutions include language describing the preferred dispositions and professional conduct that students will be expected to display while interning in the field. Student have brought suit against institutions regarding receiving sanction for not displaying the dispositions ex-

\footnotetext{
2 Dixon 294 F.2d 150, $5^{\text {th }}$ Circuit, 1961.

${ }^{3}$ W. Kaplin, B. Lee, The Law.
} 
pected of them. In Board of Curators of the University of Missouri v. Horowitz, 4 the plaintiff (a student) had been dismissed from the medical program for reasons of unsatisfactory interactions with peers and patients, as well as poor hygiene, despite having received good grades throughout her medical program. This case is indicative of the court's willingness to consider professional dispositions and standards above and beyond academic performance, as well as recognize the responsibility of those administering the program to enforce them when necessary.

The court in Dixon v. Alabama State Board of Education (1961) determined that, in instances where a particular infraction may result in the suspension or dismissal from an academic program, a student is entitled to due process, as provided for under the federal Constitution. This decision established that the minimum standard of due process is notice and the opportunity to hear evidence and present an alternate account of events leading up to sanction. Other cases, such as Esteban v. Central Missouri State College, ${ }^{5}$ have further expanded upon the range of due process rights that students possess, especially when the consequences of potential sanction increase.

\section{Method}

Three major issues are involved in the drafting or revision of policies for student conduct: the type of conduct the policy will encompass, the procedures to be used when infractions of the policy are alleged, and the sanctions for policy violations. ${ }^{6}$ Using these three standards, I will review University of Maine System education program intern handbooks for strength of language related to professional dispositions and conduct.

The following institutions provided handbooks to support this review: University of Maine, University of Maine at Farmington, University of Maine at Presque Isle, and University of Southern Maine. Other University of Maine System education departments are not included here either because they did not respond to requests to submit any published literature (as the handbooks themselves were not available through department websites), or do not maintain active teacher preparation programs. However, the programs represented here are those with the highest enrollment numbers among University of Maine System Colleges of Education.

The strength of the language/policy contained within the published handbooks will be judged against the standards described by Kaplin (above)

\footnotetext{
4435 U.S. 78, 1978.

5415 F.2d 1077, $8^{\text {th }}$ Circuit, 1967.

${ }^{6}$ W. Kaplin, B. Lee, The Law.
} 
and will determined to be weak, adequate, or strong based on the following rubric:

\begin{tabular}{|l|l|l|l|}
\hline & $\begin{array}{l}\text { Standard 1: } \\
\text { Policies address } \\
\text { specific student } \\
\text { behaviors }\end{array}$ & $\begin{array}{l}\text { Standard 2: } \\
\text { Policies include } \\
\text { descriptions of } \\
\text { procedures to be } \\
\text { used while ad- } \\
\text { dressing infrac- } \\
\text { tions }\end{array}$ & $\begin{array}{l}\text { Standard 3: } \\
\text { Sanctions for po- } \\
\text { tential infractions } \\
\text { are included in } \\
\text { existing policies }\end{array}$ \\
\hline $\begin{array}{l}\text { Strong - Policies con- } \\
\text { tain clearly stated ex- } \\
\text { pectations for intern } \\
\text { dispositions along with } \\
\text { potential consequences } \\
\text { for infractions. Descrip- } \\
\text { tions of appeals proc- } \\
\text { esses are included. }\end{array}$ & & & \\
\hline $\begin{array}{l}\text { Adequate - Policies } \\
\text { contain general expecta- } \\
\text { tions for dispositions } \\
\text { behavior and include } \\
\text { potential consequences } \\
\text { for infractions. }\end{array}$ & & & \\
\hline $\begin{array}{l}\text { Weak - Policies contain } \\
\text { either overly broad } \\
\text { language describing the } \\
\text { authority of the de- } \\
\text { partment/institution to } \\
\text { sanction students with } \\
\text { unclear expectations for } \\
\text { dispositions, or contains } \\
\text { no language regarding } \\
\text { dispositions expecta- } \\
\text { tions and enforcement } \\
\text { standards. }\end{array}$ & & & \\
\hline
\end{tabular}

\section{Analysis}

\section{University of Maine - Orono ${ }^{7}$}

The University of Maine (Orono) documents included a separate dispositions and professionalism addendum to accompany the student teacher handbook. This individual document (University of Maine Teacher and

\footnotetext{
7 University of Maine, Student Teacher Handbook, Orono, Maine 2013.
} 
Candidate Professionalism, May, 2009 - referred to as TCP for this writing) is intended to be applicable to all undergraduate field experiences, and can be found on the University of Maine College of Education and Human Development website under the Office of Field Experiences and Certification tab. The dispositions document is broken into seven sections:

1) Statement on Candidate Proficiencies

2) Expected Behaviors

3) Request for Support Form

4) Professional Growth Plan

5) Student Support System

6) Addendum/Rationale

7) References

The section of this document most relevant to Standard 1 is Section 2, "Expected Behaviors." The components of Section 2 include clearly stated expectations in the area of commitment, responsible behavior, professional communication/collaboration, confidentiality, professional appearance, and integrity/honesty. Sample language includes:

- Displays enthusiasm and optimism for teaching and learning.

- Punctuality for work in the schools and for classes.

- Collaborates with peers and school colleagues.

- Is discrete in sharing personal information with or about students, parents, and colleagues.

- Maintains professional dress consistent with the educational environment.

- Engages in behaviors and actions that reflect positively on the teaching profession.

This language (along with additional content found in the Teacher and Candidate Professionalism document) supports a "strong" characterization in terms of Standard 1 - "Policies Address Specific Student Behavior."

Standard 2 - "Policies include descriptions of procedures to be used while addressing infractions" is best satisfied by language contained in Sections 3,4 , and 5 of the TCP document. Section 3 contains a request for assistance form that may be filled out by appropriate College of Education faculty and staff when it is determined that students are running afoul (or are at risk of running afoul) of the standards of behavior expected of University of Maine interns in the field. The form requests that a specific area of need be specified, either professional (one of the seven behavioral areas listed above) or academic, as well as whether the concern is moderate or high, with separate procedures for each. The form must then be submitted to the Assistant Dean for Academic Services. 
After the form is submitted, a professional growth plan (PGP) is developed involving the student, Assistant Dean for Academic Services, the student's instructor, and the student's advisor. All parties must sign off on the PGP before it can be implemented. The PGP also contains follow-up documentation, asking College faculty and staff to make a determination as to whether the student has successfully completed the PGP, or was unsuccessful in doing so. If the student is judged to be unsuccessful, the listed options on the form include either a one-semester extension of time (if previously determined to be a "moderate" concern, the referral is then designated as a "high" concern) or a recommendation for change of program. The form allows for "other" plans to be made, however, but does not list the range of what these may be. This follow up documentation requires the signatures of the Assistant Dean for Academic Services, as well as the referred student's. The student also has the option to include a short response as part of the attachment to the PGP follow up.

Following sections 3 and 4 is a chart (Section 5, Student Support System Process) documenting the processes to be used by all stakeholders when a referral request has been made. It outlines each step in the process and also delineates between the separate characterizations of "moderate" and "high" concerns. At the bottom of the chart, all lines lead to a possible outcome of a recommendation for a change of program. The inclusion of this language may serve as notice under the federal Constitution's provision of due process. ${ }^{8}$

University of Maine's support referral system, the professional growth plan sequence, and charted procedures in Section 5 (with possible sanction including removal from a program), all support a "strong" characterization of Standard 2 (Policies include descriptions of procedures to be used while addressing infractions) and 3 (Sanctions for potential infractions are included in existing policies).

\section{University of Southern Maine ${ }^{9}$}

The submitted documents for the University of Southern Maine include a copy of the student teacher handbook. The handbook contains the following sections:

1) School of Education Core Values and Practices

${ }^{8}$ Dixon, 1961.

9 University of Southern Maine, Student Teacher Handbook, Gorham, Maine 2013. 
2) USM Teaching Standards

3) Intern Assessment System

4) The Teacher Internship

a. Intern Placement Procedure and Expectations

b. Mentor Teacher Responsibilities and Compensation

c. Supervisor Responsibilities and Compensation

d. Cohort Coordinator Responsibilities

5) Goals of the Internship Seminar

6) Internship Year Policies

a. Consent for data collection, FERPA

b. Substitute Policy

c. Teacher Duties

d. Disciplinary and Dismissal Policies

7) Appendices/Maine State Licensing Requirements

Sections $4 \mathrm{a}$ and $6 \mathrm{~d}$ are most useful for addressing Standard 1 . The description of professional conduct in section 4a includes three paragraphs describing basic expectations for punctuality/attendance, observing the stated expectations and policies of the host site (school), confidentiality, and working collaboratively with mentor teachers and site staff. Additionally, in section $6 \mathrm{~d}$, the handbook describes that students should not harass or sexually abuse students, that they should report to internships on time, should observe confidentiality policies, and defer to the authority of school officials when requests are made of them. It is important to note, however, that while the handbook does contain dispositions language, it does not clearly address a wide range of behaviors or further detail the expectations of the USM School of Education as pertains to such a range. Examples not included in the handbook could include professional dress/presentation, communication with USM faculty and staff, academic integrity, developmentally responsive teaching, etc. Since the language does include dispositions expectations, but not a wide range thereof, the determination for Standard 1 is "adequate."

Section $6 \mathrm{~d}$ further describes the process for which students will be removed from their internship. The process is as follows:

- The student will not be allowed to continue in the internship while the Advisor conducts a review.

- The Advisor will work with appropriate school personnel to obtain information regarding the allegation and will speak with the student.

- The Advisor will make a written recommendation within 14 calendar days to the Chair (of the School of Education) regarding administrative dismissal from the program. 
- The Chair will make a decision on administrative dismissal within 14 calendar days, and notify the student and the Dean of the College of Management and Human Service.

Section $6 \mathrm{~d}$ also indicates "the student has the right to appeal the decision of the Chair to the Dean of the College of Management and Human Service." The Dean's decision will be rendered within three weeks and will be final.

The overall description puts a large emphasis on "incident" management, versus dispositions and professionalism. It does include potential examples of behaviors (described above) that would result in removal, however those examples are characterized as those behaviors resulting in potential legal consequence for the student and possibly the School of Education. This "harder" perspective does not include provisions for removal based on (for example) hygiene, honesty, preparation, or other shortcomings.

Under Standard 2, the policy is determined to be strong; it clearly details the process to be used, and the process itself includes notice and an opportunity to challenge the Chair's decision. The latter provision is understood by this writer to serve as a form of hearing under due process law; the actual procedure for challenging the Chair's determination was not included in the handbook and was not otherwise known at the time of this writing.

Under Standard 3, the policy is determined to be adequate. The potential consequence of removal from a program was mentioned in the provided literature, however, this was the only potential consequence listed. By contrast, the University of Maine (Orono) literature contained a professional growth plan, perhaps indicating an overall willingness to work with students to improve performance as an interim measure prior to removal. It is important to note that the USM handbook did focus more on legal consequences for the student based on potential illegal acts. If there are similar policies and measure instituted at the USM School of Education, they were not specified in the student teacher handbook.

\section{University of Maine at Farmington ${ }^{10}$}

The (sole) document submitted by the University of Maine at Farmington (UMF) was a simple one page rubric, titled "Professional Characteristics/Personal Attributes." The rubric addressed values such as respect, organization, commitment to the profession, enthusiasm, dependability, confidentiality, and other personal and interpersonal characteristics. The

10 University of Maine at Farmington, Professional Characteristics/Personal, Attributes, Farmington, Maine 2013. 
range of the scale was simply "Needs improvement," "Basic," or "Proficient" for each listed characteristic and defined by a simple one-sentence description. For example, a "Basic" proficiency for "Respect" was defined as "Usually shows sensitivity and acceptance of others."

In terms of Standard 1 of this writing, the UMF document is determined to be adequate. It lists specific qualities and personal characteristics teacher candidates are expected to display, the range of the desired characteristics was fairly broad, and an assessment structure was included. The weakness pertaining to Standard 1 (keeping it from a "strong" characterization) is the lack of specific examples pertaining to each assessment level - the wording here is overly general and fairly brief.

Standards 2 and 3 are determined to be weak, as the document listed no procedures or possible sanctions for failing to make improvements in the stated areas. Since they were not included on the rubric in any way, additional scrutiny is not needed. If there are additional expectations and policies pertaining to student dispositions at UMF, they were not submitted by their School of Education and could not be located on their website at the time of this writing.

\section{University of Maine at Presque Isle ${ }^{11}$}

University of Maine at Presque Isle (UMPI) had submitted a copy of their student teaching handbook. The section of this handbook most relevant to the listed standards is the "Code of Conduct." The Code of Conduct is broken down into eleven different areas, all addressing professional dispositions. Examples include punctuality, use of electronic devices, familiarity with host school policies, attire, and confidentiality (among others) along with description of how student interns should approach each consideration.

In addressing Standard 1, UMPI's policy is determined to be strong. The Code of Conduct includes a range of expected behaviors along with descriptions of desirable qualities and examples in certain sections. For example (UMPI Student Teacher Handbook, 2013):

11. Be a role model and exemplify the highest standard of appearance for a teacher by demonstrating proper grooming, hygiene and attire.

- Females: Dress slacks or skirts and tops. Hemlines for skirts and dresses should be long enough not to be distracting. Halters, tank tops, see-through garments, or clothing with revealing/provocative necklines, bare backs, bare midriff, or spaghetti straps shall not be permitted.

${ }^{11}$ University of Maine at Presque Isle, Student Teacher Handbook, Presque Isle, Maine 2013. 
- Males: The expectation shall be to wear dress slacks (not jeans) and collared shirts or other appropriate professional attire.

While not all of the eleven points in the Code of Conduct contain examples for each of the eleven listed areas (as does the section on attire, listed above), the wording itself is fairly specific in terms of the desired outcome. For example ${ }^{12}$ :

\section{Turn off all electronic devices}

9. Jewelry shall not be worn in a visible pierced area other than the ear

Standard 2 is determined to be adequate. Following the Code of Conduct, the section "Withdrawal from Placement by the University" contains the following language ${ }^{13}$ :

"The University reserves the right to make a reassignment, arrange for an assignment at a later date, or permanently terminate a student teaching assignment. Such decisions will be made by the University Supervisor and the Director of Student Teaching following a review of all information relevant to the circumstances prompting the change. If a termination is made, a student may apply for re-admission by submitting a formal request to the Director of Student Teaching. The Director and the Chair of the College of Education shall review the pertinent factors related to the dismissal and the request for re- admission. An interview with the student may be requested as part of the review. The student shall be apprised of the decision for readmission following the review."

While there appears to be an existing policy making clear that the institution reserves the right to remove interns from student teaching, it does not list potential reasons for doing so. The policy does describe the procedures to be used when removing a student from the internship, but does not make clear what the student's rights are in terms of due process. The basic premises of due process are notice and an opportunity for a hearing. The policy does not describe the timeline for providing notice, nor does it indicate where in the process the student will be entitled to a hearing. One might assume that the hearing would come sometime during or after the review of evidence by the Director and Chair of the College of Education, but courts may not favor such a broad latitude the institution appears to have reserved.

Standard 3 is also determined to be adequate. While the possible sanction listed is removal from the internship, it is the only such potential sanction listed, and (as noted earlier) the conditions for its use are not clearly delineated. The lack of clarity in terms of which specific behaviors/infractions initiate the removal process and the omission of language

12 UMPI Student Teacher Handbook, 2013.

${ }^{13}$ Ibidem. 
describing a student's rights to due process are areas (in this writer's opinion) that could be improved in the UMPI student handbook policies. While a student might assume that removal is due to an infringement of the code of conduct, it is not clearly stated in the policy that a potential consequence of offending the code is removal. Nor does it say which particular standards carry more weight than others; Will infringing upon only one of the eleven listed conduct areas result in removal or will it require multiple infractions? Will the student be given the opportunity to improve in these areas before being removed from his/her program or not? The answers to these questions are not found in the UMPI student teacher handbook.

\section{Conclusion}

I have placed the four contributing institutions in the original matrix structure according to the determined strengths and weaknesses as determined in the analysis section of this writing.

(see next page)

\begin{tabular}{|c|c|c|c|}
\hline & $\begin{array}{l}\text { Standard 1: } \\
\text { Policies address } \\
\text { specific student } \\
\text { behaviors. }\end{array}$ & $\begin{array}{l}\text { Standard 2: } \\
\text { Policies include } \\
\text { descriptions of } \\
\text { procedures to be } \\
\text { used while ad- } \\
\text { dressing infrac- } \\
\text { tions. }\end{array}$ & $\begin{array}{l}\text { Standard 3: } \\
\text { Sanctions for po- } \\
\text { tential infractions } \\
\text { are included in } \\
\text { existing policies. }\end{array}$ \\
\hline $\begin{array}{l}\text { Strong - Policies con- } \\
\text { tain clearly stated ex- } \\
\text { pectations for intern } \\
\text { dispositions along with } \\
\text { potential consequences } \\
\text { for infractions. Descrip- } \\
\text { tions of appeals proc- } \\
\text { esses are included. }\end{array}$ & $\begin{array}{l}\text { University of } \\
\text { Maine } \\
\text { University of } \\
\text { Maine - Presque } \\
\text { Isle }\end{array}$ & $\begin{array}{l}\text { University of } \\
\text { Maine } \\
\text { University of } \\
\text { Southern Maine }\end{array}$ & $\begin{array}{l}\text { University of } \\
\text { Maine }\end{array}$ \\
\hline $\begin{array}{l}\text { Adequate - Policies } \\
\text { contain general expecta- } \\
\text { tions for dispositions } \\
\text { behavior and include } \\
\text { potential consequences } \\
\text { for infractions. }\end{array}$ & $\begin{array}{l}\text { University of } \\
\text { Southern Maine } \\
\text { University of } \\
\text { Maine - Farming- } \\
\text { ton }\end{array}$ & $\begin{array}{l}\text { University of } \\
\text { Maine - Presque } \\
\text { Isle }\end{array}$ & $\begin{array}{l}\text { University of } \\
\text { Southern Maine } \\
\text { University of } \\
\text { Maine - Presque } \\
\text { Isle }\end{array}$ \\
\hline $\begin{array}{l}\text { Weak - Policies contain } \\
\text { either overly broad } \\
\text { language describing the } \\
\text { authority of the de- }\end{array}$ & & $\begin{array}{l}\text { University of } \\
\text { Maine - Farming- } \\
\text { ton }\end{array}$ & $\begin{array}{l}\text { University of } \\
\text { Maine - Farming- } \\
\text { ton }\end{array}$ \\
\hline
\end{tabular}




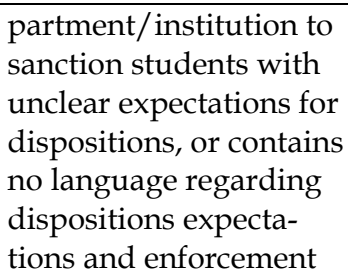

Only one institution (University of Maine) scored a "strong" characterization in each of the three Standard categories. Two institutions (University of Southern Maine and University of Maine at Presque Isle) scored one "strong" characterization in particular standards, as well as scoring two "adequate" characterizations in particular standards. One institution (University of Maine at Farmington) scored a single "adequate" characterization in a particular standard, along with two "weak" characterizations in two standards.

The limitations of this review are that there may be additional policies listed in such sources as departmental handbooks (non-student teacher handbooks) or in institutional catalogues that may have led officials to determine a certain overlap was unnecessary in listing them again in student teacher handbooks. However, there was no indication that students should refer to other institutional documents as a point of reference. Also, these documents are typically "in flux" in that they are constantly being developed as situations and needs arise. The handbooks submitted by the four institutional departments are merely "snapshots" in time in terms of where the policies currently stand; they may have already changed at the time of this writing.

\section{BIBLIOGRAPHY}

Board of Curators of the University of Missouri v. Horowitz, 435 U.S. 78, 1978.

Dixon v. Alabama State Board of Education, 294 F.2d 150, 5th Circuit, 1961.

Esteban v. Central Missouri State College, 415 F.2d 1077, 8th Circuit, 1967.

Kaplin W., Lee B., The Law of Higher Education, Jossey Bass, San Francisco 2007.

University of Maine, Student Teacher Handbook, University Print Office, Orono, Maine 2013.

University of Maine at Farmington, Professional Characteristics/Personal, Attributes, Farmington, University Print Office, Maine 2013.

University of Maine at Presque Isle, Student Teacher Handbook, Presque Isle, University Press, Maine 2013.

University of Southern Maine, Student Teacher Handbook. Gorham, University Press, Maine 2013. 